\title{
DO INTERNATIONAL ECONOMIC DEVELOPMENTS AFFECT THE South African ECONOMY?
}

\author{
JA Swanepoel ${ }^{1}$
}

South African Reserve Bank

\begin{abstract}
Globalisation has opened economies more, exposing them to more international shocks and increasing the challenges to which domestic economic policies must respond. This paper provides a starting point for the analysis of the impact of international economic developments on the South African economy by means of graphical illustrations, correlations coefficients and in some cases a VAR analysis. Although this paper has shed some light on the importance of international economic developments on the South African economy, more rigorous econometric investigation is needed to validate the arguments and to address many of the unresolved questions.
\end{abstract}

JEL F41, F43

\section{1}

\section{Introduction and background}

Because of the rapid advance of globalisation of the world economy, economic developments in one country can be significantly influenced by developments in other countries. Consequently, economies are more vulnerable to international economic developments. External factors have a particular impact on economic policy. External shocks, for example, have a greater influence on South Africa's inflation-targeting monetary policy framework and there has been increasing research regarding external factors and their impact on South African inflation (see Swanepoel, 2005). In addition to their impact on domestic inflation, international economic developments could affect a domestic economy in various other ways.

This study explores some of these influences and assesses the impact of international economic developments on the South African economy. Important aspects to consider, are the recent record high oil prices, strong movements in the exchange rate of the rand and occurrences of international natural disasters, financial crises, diseases, wars etc. This study focuses on the three aspects: oil prices, the exchange rate and openness to international trade. In general, the analysis is based on graphical illustrations. In some cases, econometric techniques were used to support graphs. The third section is the conclusion.

\section{2 \\ International economic conditions and their impact on the South African economy}

\subsection{Oil prices}

Oil is intrinsically volatile due to its widespread use both as input factor in the production process and as final consumption good and therefore has a major influence on the global economy. Both economic theory and the empirical evidence link rising oil prices to real gross domestic input (GDP) losses (Brown \& Yucel, 2001: 20). According to the November European Central Bank Monthly Bulletin (2004: 53), oil price shocks work through traditional supply and demand channels, although additional channels can also play a role. The 
supply-side channel originates from the fact that oil represents an important input factor in the production process. Oil price increases lead to an increase in production costs, because there are limited substitutes for oil, particularly in the short term. As a result of the increased cost of oil, the level of domestic output could decline, which may also lead to lower demand for production factors like labour. On the demand side of the economy, an increase in oil prices entails a deterioration in the terms-oftrade of net oil-importing economies. Consequently, income will be redistributed from net oil-importing to net oil-exporting economies. The decline in real income in net oil-importing countries associated with an oil price shock translates into lower domestic demand to the extent that it is not compensated for by reduced saving or increased borrowing. Moreover, if a country's trading partners are predominantly net oil-importing countries, the decline in domestic demand is likely to be accompanied by lower export demand. The negative impact of an oil price shock on activity resulting from the basic "cost-push" and demand-side effects, may be exacerbated through a number of additional channels like its impact on consumer or investor confidence. The adverse economic impact of higher oil prices on oil-importing developing countries is generally more severe than for Organisation for Economic Co-operation and Development (OECD) countries, as developing countries are more dependent on imported oil and are more energy-intensive because energy is used less efficiently (International Energy Agency, 2004: 2). Developing countries are also less able to weather the financial turmoil wrought by higher oil-import costs.

Figure 1 illustrates that rapidly rising oil prices in South Africa have generally preceded recessions. In recent years, however, rising oil prices appear to have had less of an effect on economic activity. Rising oil prices therefore need not necessarily mean a recession.

Figure 1

Oil prices and economic growth

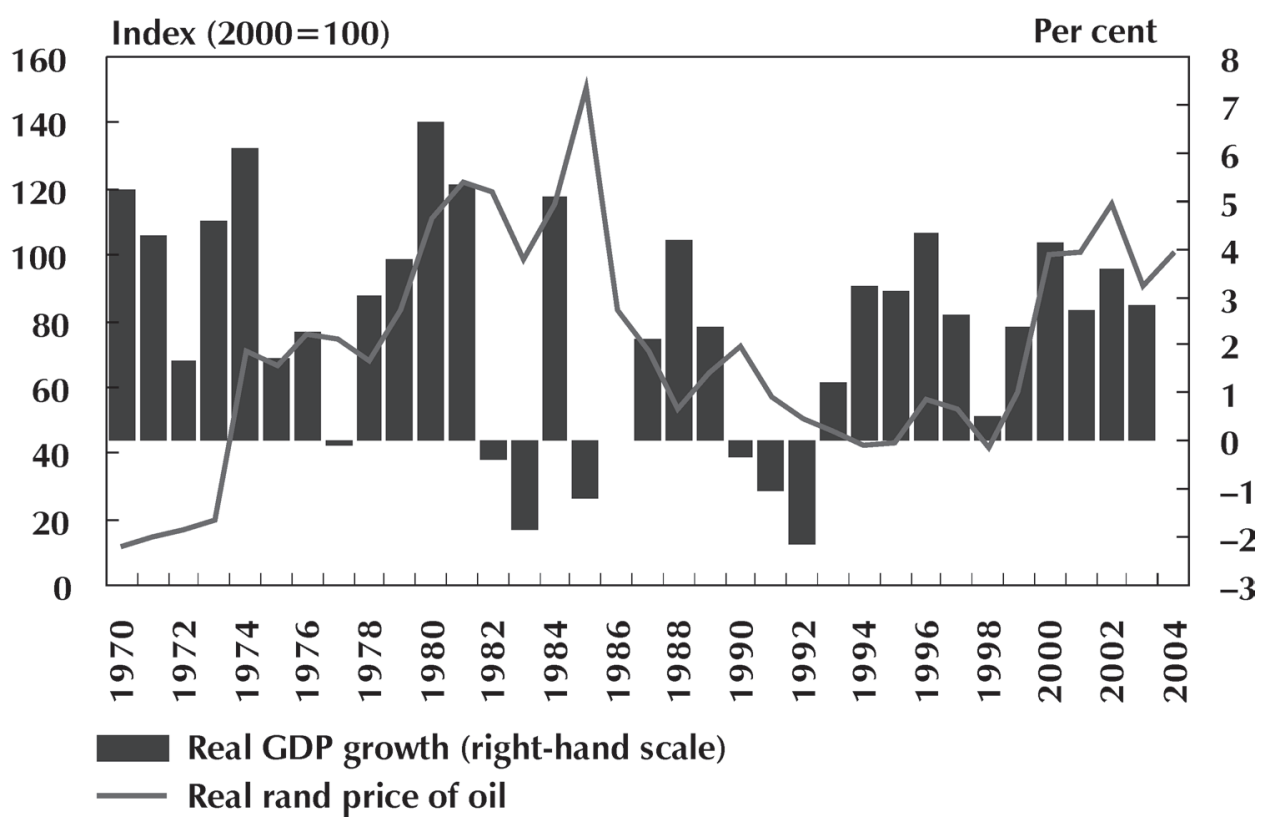

Source: South African Reserve Bank and own calculations 
Oil prices in US dollars rose to record levels in nominal terms during 2004. There are, however, key differences between this increase and previous oil price shocks. Table 1 illustrates that the increase in 2004 was considerably smaller than those observed during the other major oil price shocks. On average, the price of Brent crude oil (in US dollars) in 2004 was 32.1 per cent higher than in 2003. In rand terms, the annual rate of change in the oil price was lower (12.6 per cent) due to the appreciation of the rand against the US dollar. After taking inflation into account, i.e. in real terms, the rate of change was even lower (11.1 per cent) in 2004 compared to earlier episodes of high prices. The factors driving the oil price increase in 2004 differed from earlier periods of oil price shocks. In contrast to the oil price increases of 1973, 1979, 1990 and 1999, which were mainly caused by sizeable disruptions in the supply of oil, a variety of factors had an impact on oil prices in 2004. These factors include buoyant demand for oil that surpassed expectations, the dwindling global spare capacity and concerns over the security of supplies from several oilproducing countries.

Table 1

Increase in Brent crude oil prices over specific periods

Percentage change

\begin{tabular}{|l|c|c|c|c|}
\hline & $\mathbf{1 9 7 3 - 1 9 7 4}$ & $\mathbf{1 9 7 8 - 1 9 7 9}$ & $\mathbf{1 9 9 9 - 2 0 0 0}$ & $\mathbf{2 0 0 3 - 2 0 0 4}$ \\
\hline in US dollar & 314.8 & 44.2 & 58.4 & 32.1 \\
\hline in rand & 307.0 & 39.6 & 79.7 & 12.6 \\
\hline real rand price of oil & 263.7 & 23.2 & 70.6 & 11.1 \\
\hline
\end{tabular}

Oil prices and South African interest rates moved rather closely together until the late 1990s with a statistically significant correlation coefficient of 0.4 (see Figure 2). Since about 1999, however, interest rates have not risen with oil prices. This suggests that monetary policy has become less sensitive to oil price shocks. Figure 3 illustrates a positive relationship between oil prices and CPI inflation in South Africa (statistically significant correlation coefficient of 0.3 ).

\section{Figure 2}

Oil prices and interest rates

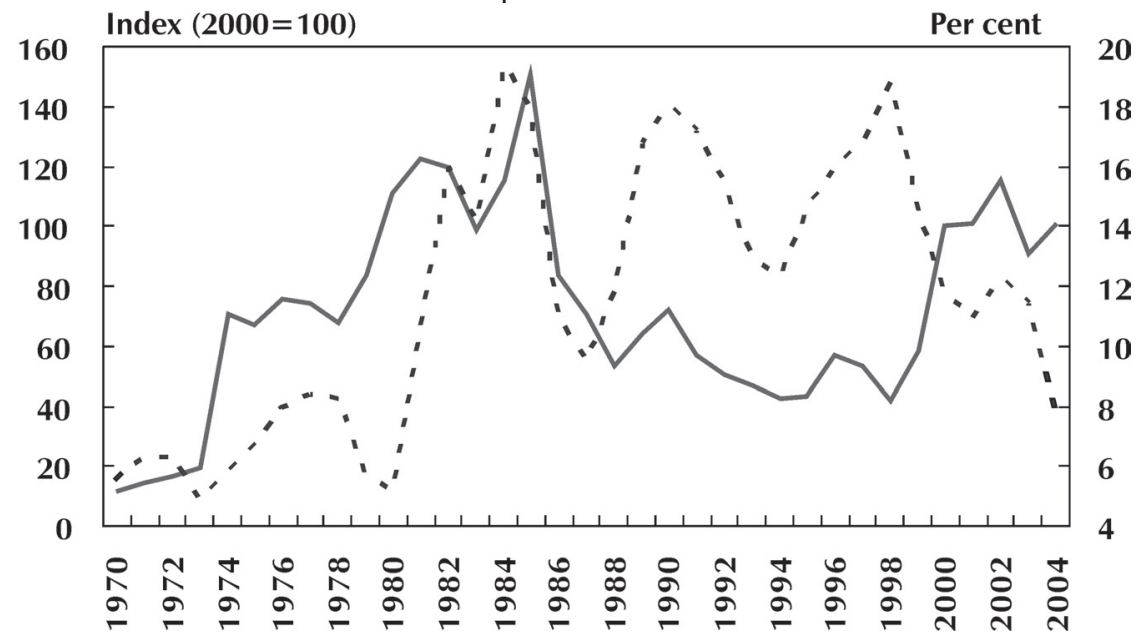

- Real rand price of oil

- - - - Bank rate (right-hand scale) 


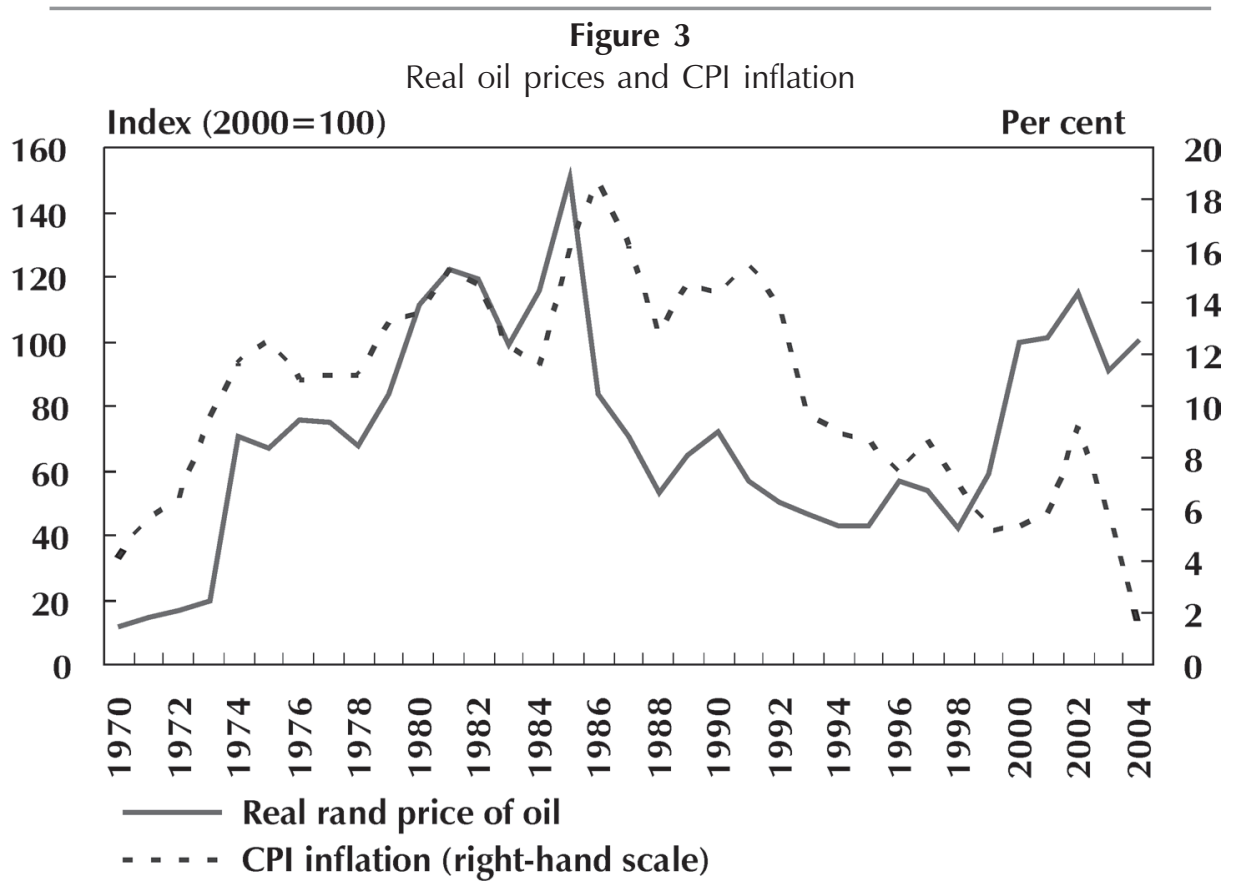

Source: South African Reserve Bank and own calculations

Empirical results to support the graphical representations were obtained by means of a VAR analysis. Identification of the shocks of the model is achieved through a Cholesky decomposition. Information on the size and speed of the pass-through of oil price shocks on different variables, is derived from impulse response functions. The analysis is based on quarterly data covering the period 1981:Q1 to 2004:Q4. This represents the longest time period for which data could be obtained for all variables used in the model. The variables included in the model were real GDP (gdp), the overall consumer price index (cpi), the real rand price index of oil (oilp), the official interest rate (ofr), a short-term interest rate (str) and a long-term interest rate $(\mathrm{ltr})^{2}$. The model reflects the relationship between oil prices, aggregate economic activity, financial variables and inflation. Tests of lag order selection were used to determine the lag intervals for the endogenous variables in the VARs. Unit root tests were performed in order to assess the time series properties of the data. The results of the Augmented Dickey Fuller (ADF) tests are summarised in Table 2. The tests indicate that real GDP (gdp), consumer prices (cpi), the real rand price index of oil (oilp), the short-term interest rate (str) as well as the long-term interest rate variable (ltr) are integrated of order one, $\mathrm{I}(1)$, while the official interest rate variable (ofr) is a stationary series, $\mathrm{I}(0)$.

Table 2

Unit root tests

\begin{tabular}{|l|c|c|c|}
\hline \multicolumn{4}{|c|}{ ADF Tests } \\
\hline Variable & Constant & Constant with trend & Decision $^{3}$ \\
\hline gdp & 0.9 & -1.85 & $\mathrm{I}(1)$ \\
\hline$\Delta$ gdp & $-4.7^{* * *}$ & $-3.8^{*}$ & \\
\hline
\end{tabular}




\begin{tabular}{|l|l|l|c|}
\hline OFR & $-3.2^{* *}$ & $-3.5^{* *}$ & $\mathrm{I}(0)$ \\
\hline cpi & $-3.6^{* * *}$ & -0.3 & $\mathrm{I}(0) / \mathrm{I}(1)$ \\
\hline$\Delta$ cpi & $-2.9^{* *}$ & $-5.4^{* * *}$ & $\mathrm{I}(1)$ \\
\hline oilp & -2.28 & -2.16 & $-4.3^{* * *}$ \\
\hline$\Delta$ oilp & $-3.6^{* * *}$ & $-3.3^{*}$ & $\mathrm{I}(1)$ \\
\hline STR & $-2.6^{*}$ & $-3.8^{* *}$ & $\mathrm{I}$ \\
\hline$\Delta$ STR & $-3.4^{* *}$ & -1.8 & $\mathrm{I}(1)$ \\
\hline LTR & -1.4 & $-4.8^{* * *}$ & \\
\hline$\Delta$ LTTR & $-3.9^{* * *}$ & & \\
\hline
\end{tabular}

Notes: Variables in small caps indicate logs of variables

$\Delta$ indicates the change in variables

* indicates significance at the 10 per cent level

** indicates significance at the 5 per cent level

*** indicates significance at the 1 per cent level

Data source: South African Reserve Bank

The ordering of variables is indicated by the vector of endogenous variables:

$\mathrm{X}=(\Delta \mathrm{gdp}, \Delta \mathrm{cpi}, \Delta$ oilp, ofr, $\Delta \mathrm{str}, \Delta \mathrm{ltr})$

Several lag order selection criteria were used to determine the lag order of the VAR model. Taking into account the results of the lag order selection criteria, a VAR model was estimated with a constant and one lag. A VAR model is estimated ${ }^{4}$ in first differences of the variables, where necessary.

Figure 4 shows the impulse responses to an oil price shock. The results show that a positive oil price shock leads to a decline in real GDP and increases in consumer prices and short- and long-term interest rates, as expected. The responses, however, are not statistically significant.

\section{Figure 4}

Impulse responses of an oil price shock Accumulated Res ponse to Choles ky One S.D. Innovations \pm 2 S.E.
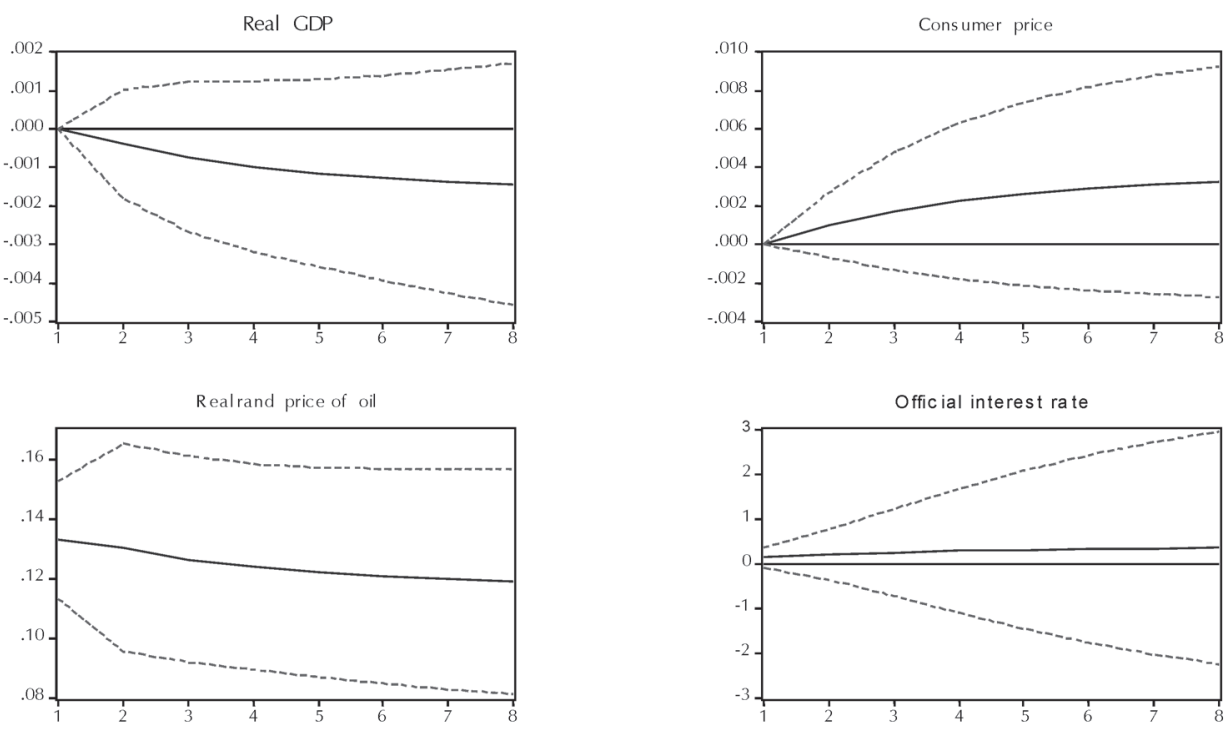


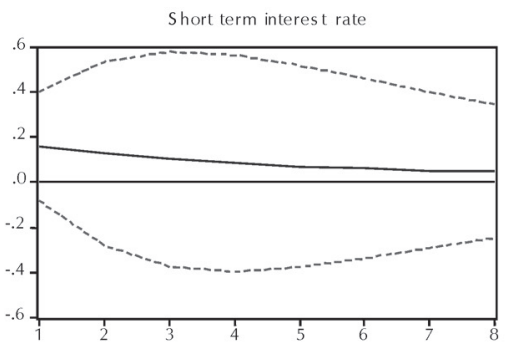

Oil price changes could have secondary effects on confidence levels and the stock market. Figure 5 illustrates the impact of oil prices on the South African stock market. For comparative reasons, the sample period is the same as that of the VAR analysis. The influence of oil prices is examined by comparing the average stock returns for the FTSE/JSE allshare index and its sectors during the periods in which all prices were in a low/middle range or in a high range. The high rate is defined as an upward deviation from the average real oil price in the period January 1981 to December 2004

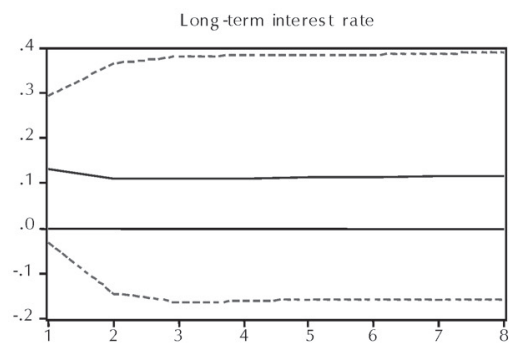

of more than 10 per cent. The average monthly stock returns are displayed under the different oil price regimes. Overall, the FTSE/JSE allshare index on average increased by around 1.2 per cent per month during periods of low/ medium oil prices, but performed much worse during periods of high oil prices. The performance differed significantly across sectors. In general, mining seemed to be least affected by higher oil prices (compared to the overall index), while financials underperformed the worst.

\section{Figure 5}

The impact of oil prices on the stock market

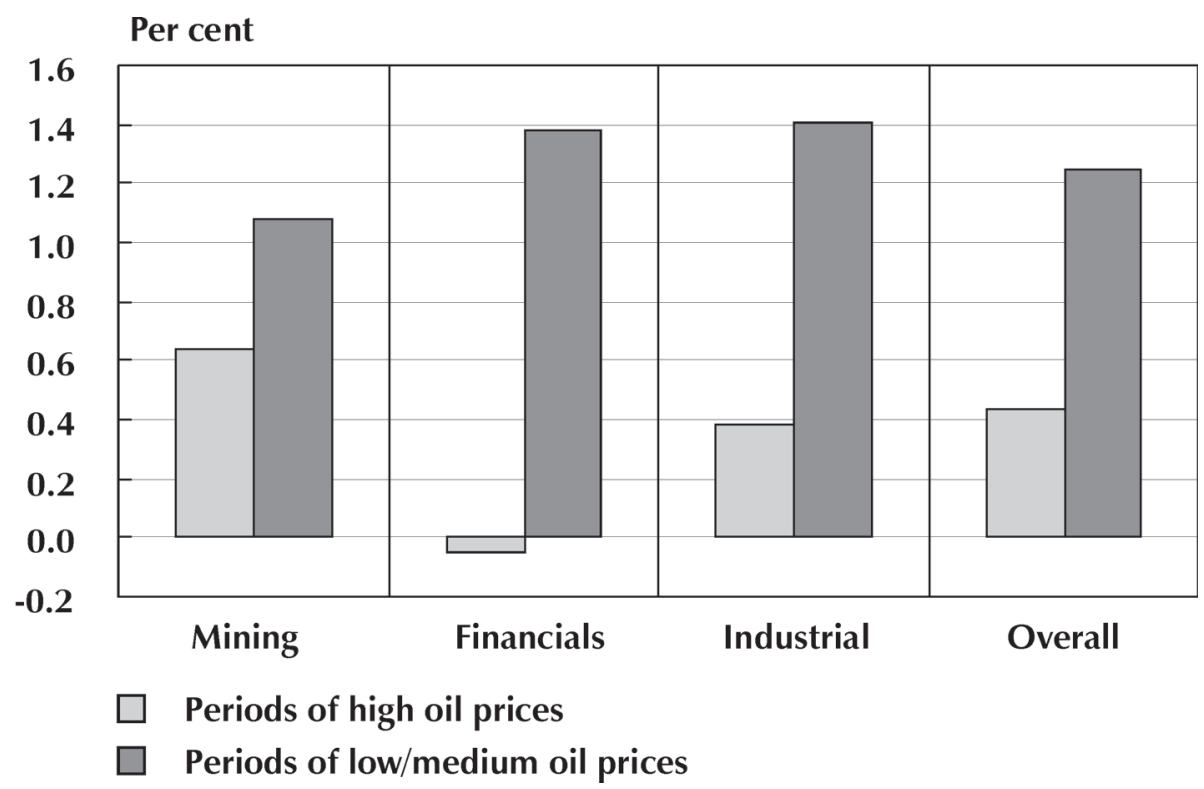

Note: High oil prices refer to upward deviations from the average real oil price (Brent crude oil price deflated by the CPI) of more than 10 per cent, for the period January 1981 to December 2004. Low/medium oil prices refer to oil prices below this threshold. 
In summary, the graphical illustrations demonstrate that past periods of rising oil prices have generally resulted in lower South African real GDP growth, higher prices and higher interest rates. Oil price shocks also seem to have been an important source of volatility in short-term interest rates and consumer price inflation. The impact of oil price shocks on the South African economy, however, seems to have decreased in recent years. Empirical results (although not significant) indicate that a positive oil price shock leads to a decline in real GDP and increases in consumer price inflation and shortand long-term interest rates. Oil price increases also impact negatively on the South African stock market, especially the financial sector.

\subsection{Exchange rates, speculation, sentiment and contagion effects}

Exchange rate shocks also pose a significant potential risk to domestic economic growth. Trade globalisation has boosted import and export volumes, therefore changes in the exchange rate now affect a greater portion of aggregate demand. Changes in exchange rates can affect economic activity through a number of channels. Four of the most important of these are price competitiveness, terms of trade, domestic capital costs and profitability channels (European Commission, 2004: 21). Figure 6 relates the real effective exchange rate of the rand to the 1990-2003 average. The period since 1990 was chosen in order to analyse the impact of the most recent exchange rate movements, particularly the large depreciation phase during 2001 and the subsequent large appreciation phase since 2002. The real effective exchange rate of the rand, for a prolonged period since mid-1998, remained below its 1990-2003 average. It depreciated by around 40 per cent between April 1997 and December 2001 and has appreciated by around 60 per cent since then. The real effective exchange rate of the rand was around 5 per cent above its long-term average by the end of 2004 .

Figure 6

Real effective exchange rate of the rand

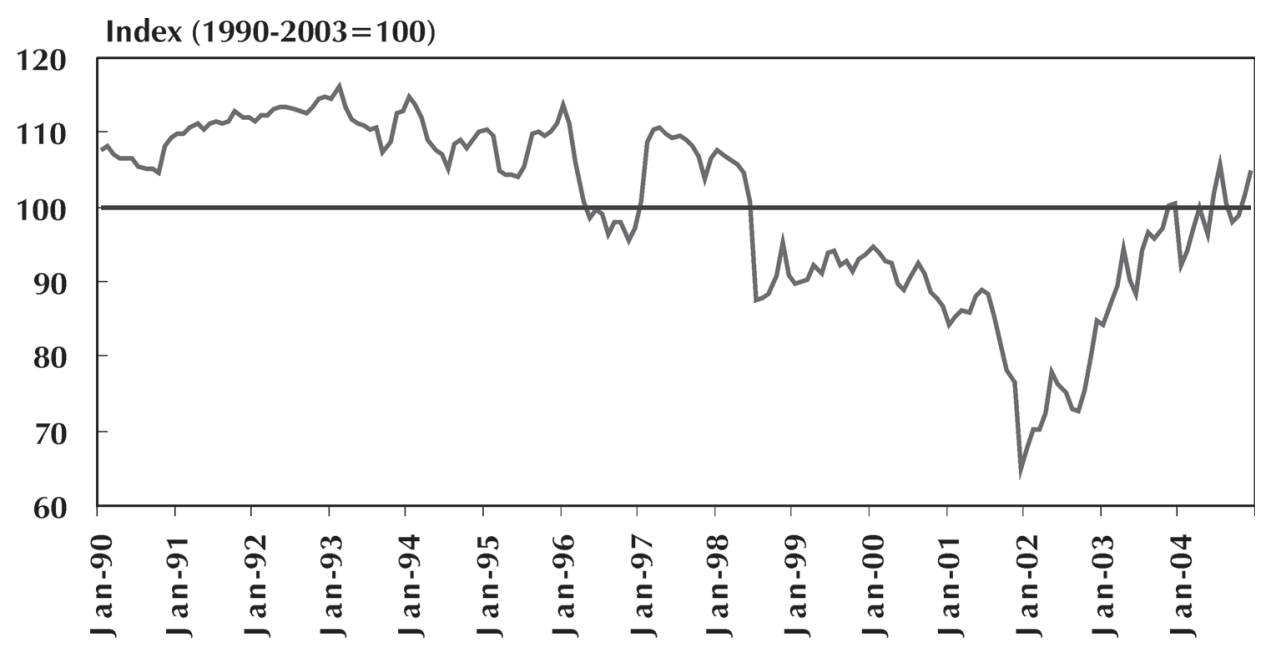

Source: South African Reserve Bank and own calculations

As an immediate result of the appreciation, exporters in recent years should have suffered a significant loss in international price competitiveness. Figure 7 sets out the impact of price competitiveness on South Africa's net export contribution to annual real GDP growth.
In general, the expected negative relationship between the two series is not that clear (with a statistical significant correlation coefficient of -0.3). Other factors that clearly also play a role in South Africa's net exports over time, are the expansion in world trade on export growth and 
domestic demand on import growth. Tsikata (1999: 14-15) found that exchange rate depreciation and trade liberalisation, stimulated improved export performance in South Africa during the period 1970 to 1996, while sanctions lowered exports. Exports were found to be highly sensitive to real exchange rates, world demand and trade policy. It could be that the sensitivity of South African exports to variations in exchange rates was relatively small compared with the impact of developments in world import demand. It is therefore likely that a rebound in world trade more than offsets the impact of the loss in price competitiveness. There could be various other explanations for the muted response of net exports to changes in the real effective exchange rate, such as the availability of financial hedging instruments and/or pricing to market behaviour.

Figure 7

Net export performance and the real effective exchange rate $^{5}$

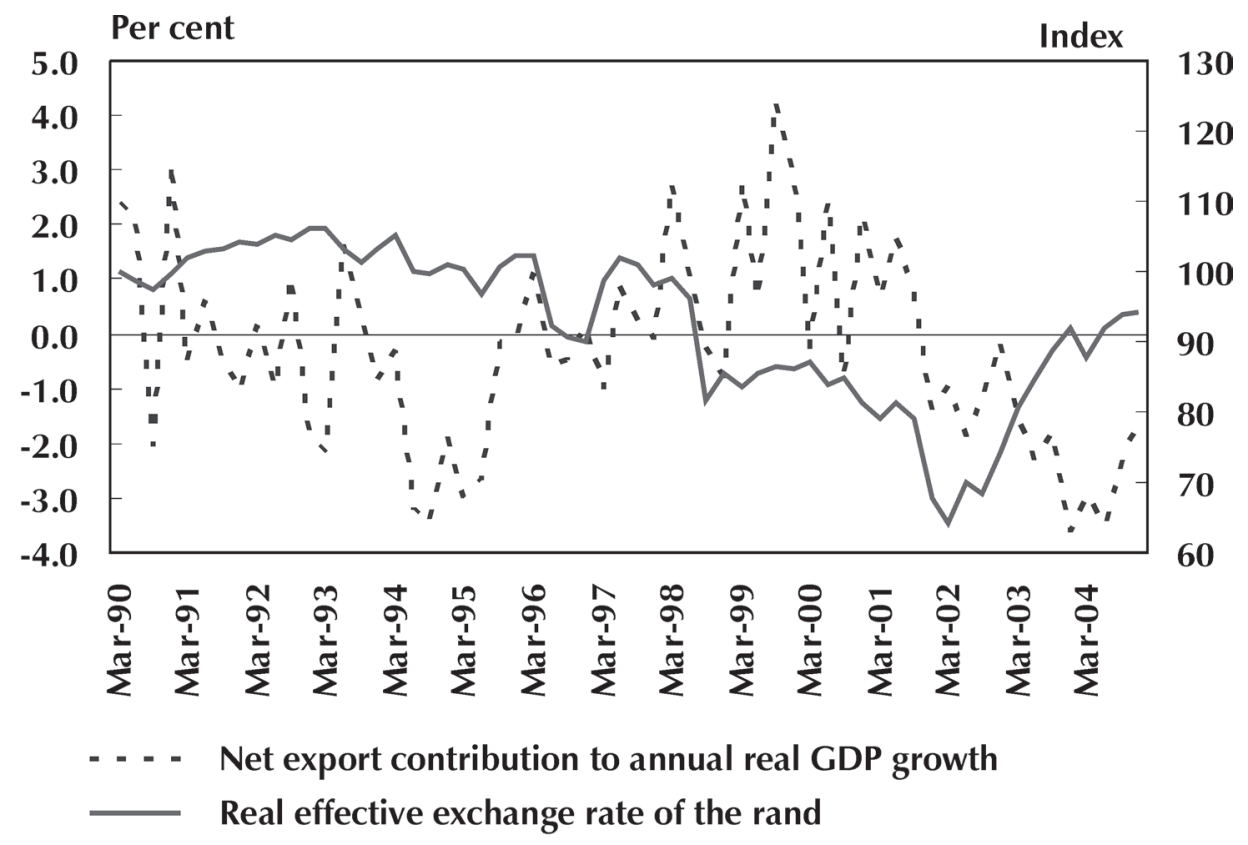

Source: South African Reserve Bank and own calculations

In addition to the effect on net exports, exchange rate movements may impact on economic activity through capital flows and economic confidence. Pertaining to capital flows, a country could hope to benefit from a smaller risk premium, and thereby lower capital costs, if the exchange rate appreciation was caused by a shift in relative risk preferences towards domestic country investments (European Commission, 2004: 30). Such a shift in relative risk preferences should show up in a redirection of capital flows in the balance of payments. Figure 8 illustrates trends in net portfolio investment flows and the real effective exchange rate in South Africa. A clear positive relationship can be observed between net portfolio investment flows and the exchange rate (statistical significant correlation coefficient of 0.3 ). 
Figure 8

Net portfolio investment and the real effective exchange rate ${ }^{4}$

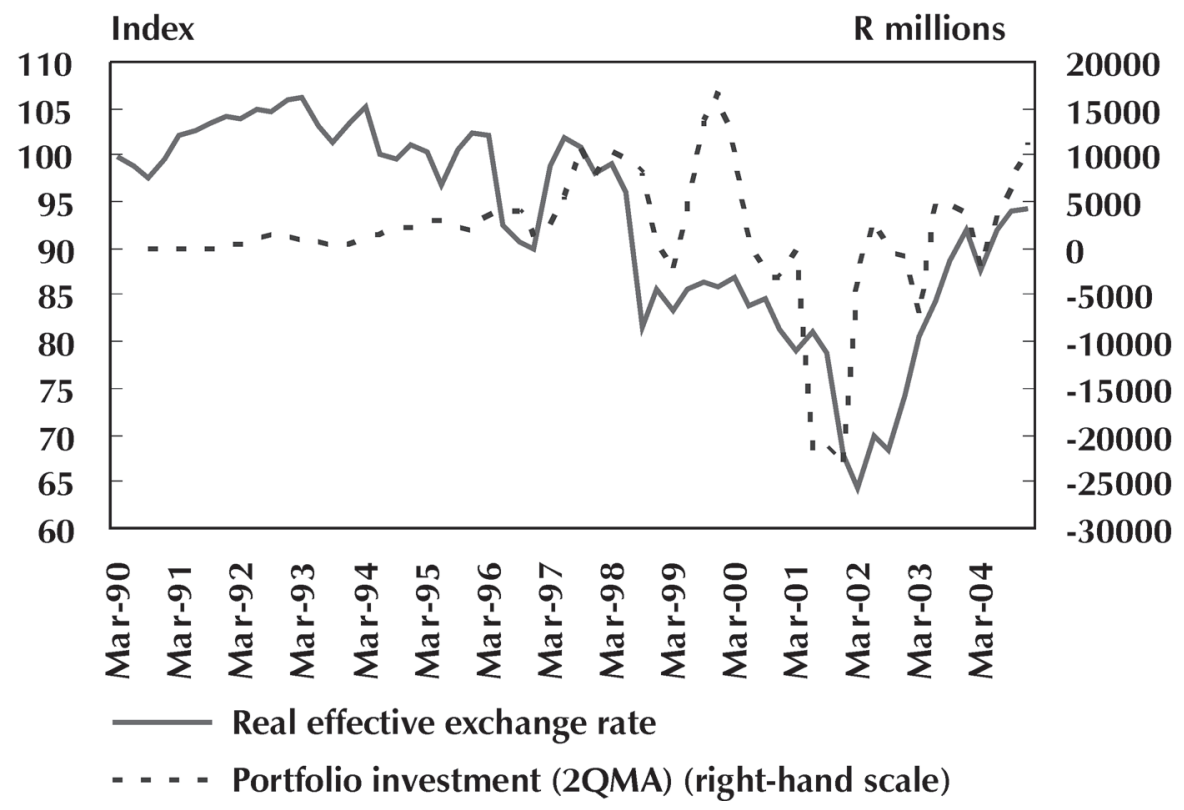

Source: South African Reserve Bank and own calculations

Changes in the exchange rate also affect revenues from capital income abroad, which has a detrimental impact on the cash position of South African residents and possibly also on their investment behaviour. Figure 9 illustrates the negative relationship between the nominal effective exchange rate and income from investment abroad (statistical significant correlation coefficient of -0.9). South African residents heavily invested abroad when the rand was strong and realised capital losses when the rand appreciated.

Figure 9

Investment income from abroad and the nominal effective exchange rate

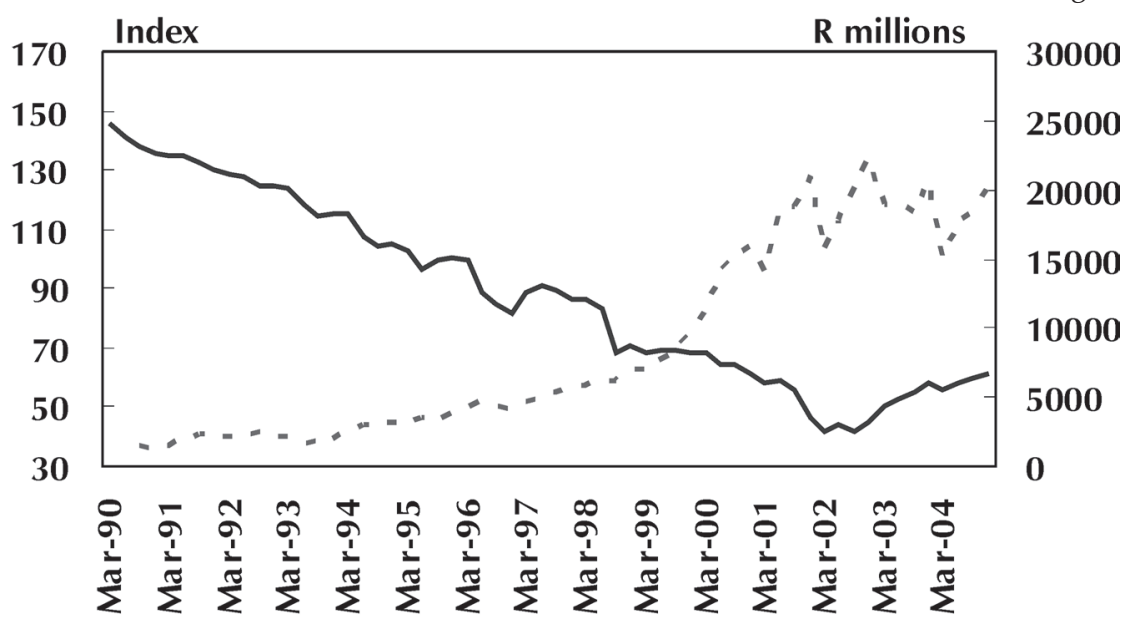

Nominal effective exchange rate 
The impact of exchange rate changes on economic confidence potentially constitutes a further important transmission channel. In particular, if exchange rates record historical highs or lows, emphasis in the news is high and the public perceives the exchange rate to be more important than during ordinary times. This might affect their perception of the economic outlook in general and their business or employment prospects in particular (European Commission, 2004: 31). Figures 10 and 11 illustrate that in general consumer and business confidence in South Africa have tracked movements in the exchange rate better since 1995, when the South African economy was opened up for foreign trade after the first democratic elections.

Figure 10

Business confidence and the real effective exchange rate
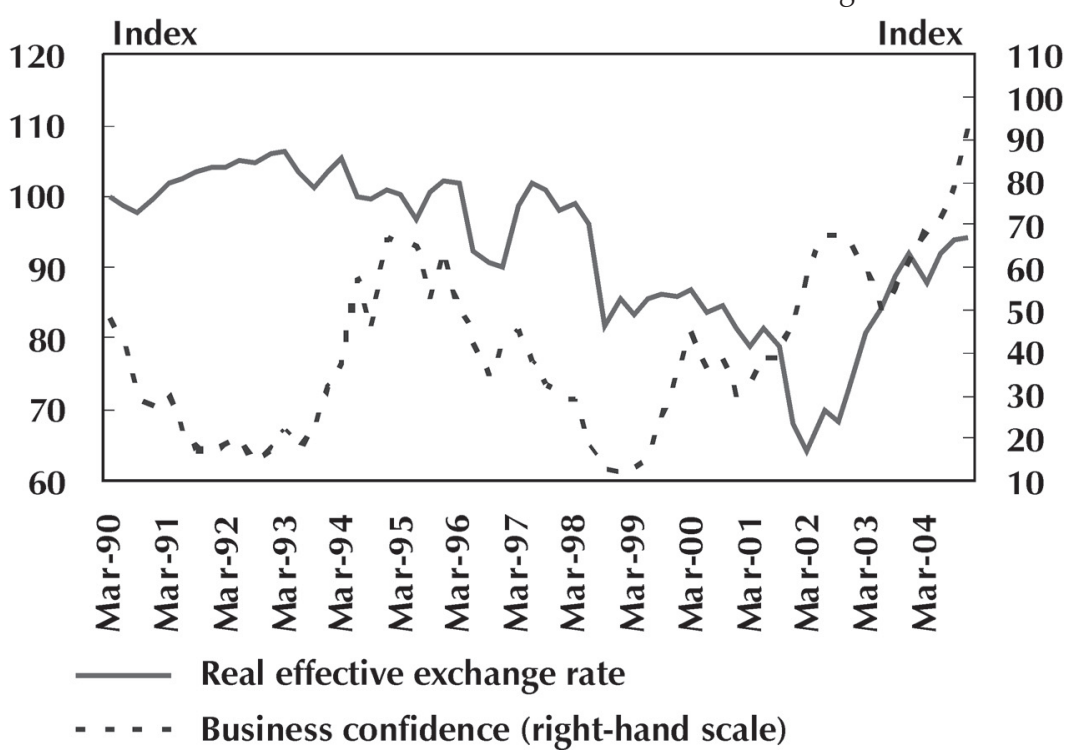

Source: South African Reserve Bank, Bureau for Economic Research and own calculations

\section{Figure 11}

Consumer confidence and the real effective exchange rate

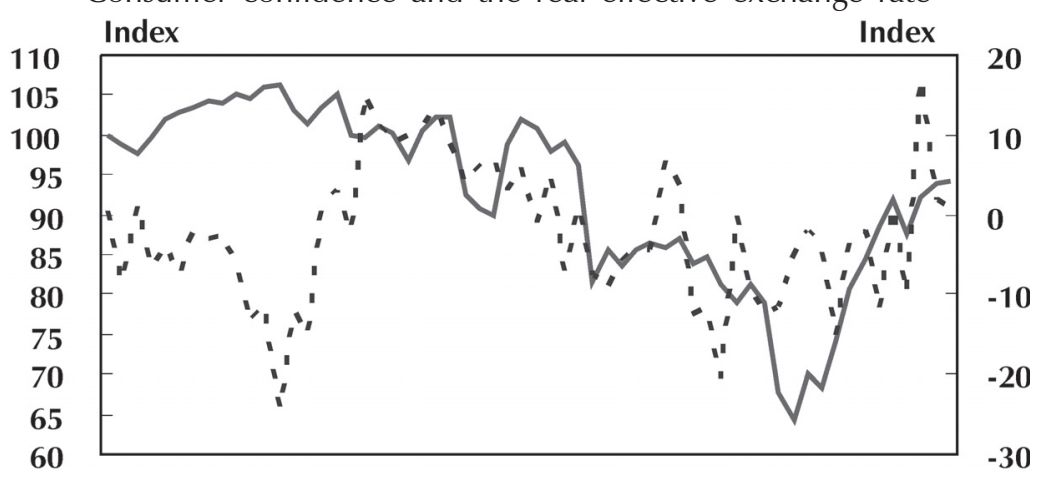

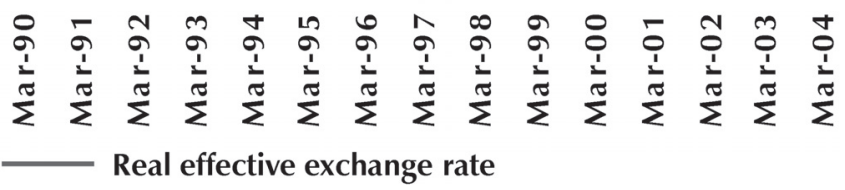

\section{- - - - Consumer confidence (right-hand scale)}

Source: South African Reserve Bank, Bureau for Economic Research and own calculations 
It seems as if political news, speculative attacks and contagion effects have become increasingly important factors affecting the domestic currency compared to domestic economic developments or balance-of-payment issues during the 1990s. This fact is illustrated by means of Table 3 which shows that recent large currency depreciation episodes (depreciations in excess of 10 per cent) appear to be unrelated to economic or financial imbalances. International economic developments such as international market crises and speculative attacks on the currency and sentiment, have therefore played a large role in domestic currency movements since the mid-1990s. These factors also hold potential implications for domestic economic growth via its impact on the exchange rate.

Table 3

Large rand depreciation episodes and economic conditions

\begin{tabular}{|c|c|c|c|c|c|}
\hline & 1996 & 1998 & 1999 & 2001 & 2002 \\
\hline Exchange rate $^{1}$ depreciation & -11.4 & -12.9 & -10.9 & -15.1 & -21.7 \\
\hline CPI inflation & 7.4 & 6.9 & 5.2 & 5.7 & 9.2 \\
\hline Real GDP growth & 4.3 & 0.5 & 2.4 & 2.7 & 3.6 \\
\hline Current account (\% GDP) & -1.2 & -1.8 & -0.5 & 0.1 & 0.7 \\
\hline Financial account ${ }^{2}$ (\% GDP) & 0.5 & 1.2 & 3.6 & 0.6 & 2.5 \\
\hline Imports covered by reserves ${ }^{3}$ & 5.3 & 11.4 & 12.9 & 17.7 & 19.4 \\
\hline Annual change in the terms of trade ${ }^{4}$ & 4.4 & -2.5 & -3.7 & 1.2 & 2.4 \\
\hline Budget balance (\% GDP) & -4.9 & -3.3 & -2.1 & -0.7 & -0.7 \\
\hline
\end{tabular}

Notes: 1) Nominal effective exchange rate of the rand

2) Including unrecorded transactions

3) Number of weeks

4) Including gold

Source: South African Reserve Bank and own calculations

\subsection{Openness to trade and developments in trading-partner countries}

In summary, the recent loss in international price competitiveness does not seem to have had a major impact on South Africa's export performance. However, this can probably be ascribed to strong growth in trading-partner countries, which compensated for the loss in price competitiveness. The analysis has shown that exchange rate movements are related to capital flows and confidence levels in South Africa. Finally, political news, speculative attacks and contagion effects have become increasingly important factors affecting the domestic currency compared to domestic economic conditions or balance-of-payment issues during the 1990s.
According to Baldwin (2003: 1) there is still disagreement among economists concerning the way a country's international economic policies and its rate of economic growth interact. However, a number of multi-country case studies utilising comparable and analytical frameworks, numerous econometric studies using large cross-country data sets, and important theoretical advances in growth theory prove this fact. One would generally expect a country's economic growth to be positively influenced by growth experienced by its trading partners, reflecting both supply and demand effects (Arora \& Vamvakidis, 2001: 4). An increase in trading-partner countries' economic 
growth rates could contribute to higher import demand, which is reflected directly in an increase in the contribution of net exports to GDP growth in a domestic economy. The impact of trading-partner countries on domestic economic growth could also be transmitted through other channels beyond the direct impact of net exports. These include factors such as capital account linkages, co-movements in consumer and business sentiment and the role of significant markets (such as the United States) on international finance (Arora \& Vamvakidis, 2001: 12). Trading-partner countries could also be an important potential source of global instability. Finally, changes in the policy stance of trading-partner countries could also impact on domestic growth (Ehrmann, Fratzscher \& Rigobon, 2004).

Openness to trade creates opportunities to enhance growth through international trade. South Africa is a small open economy and it could therefore be expected that openness and growth are closely related. Figures 12 and 13 support this fact in general, by illustrating that openness (defined as the sum of imports and exports as a ratio of GDP) as well as world trade volume growth, is positively correlated to real GDP growth in South Africa (statistical significant correlation coefficients of 0.4 and 0.3 respectively).

\section{Figure 12}

Openness of the South African economy and economic growth
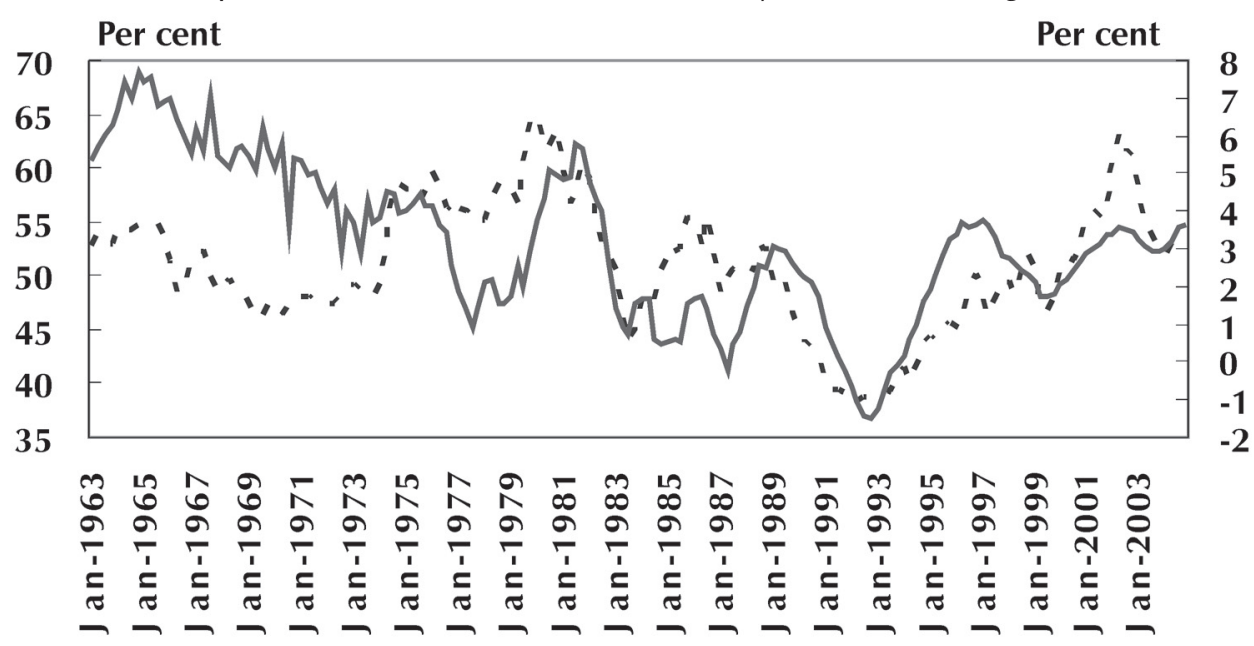

- - - Openness (two-quarter moving average)

GDP growth (12-quarter moving average) (right-hand scale) 


\section{Figure 13}

Per cent

World trade volume growth and economic growth

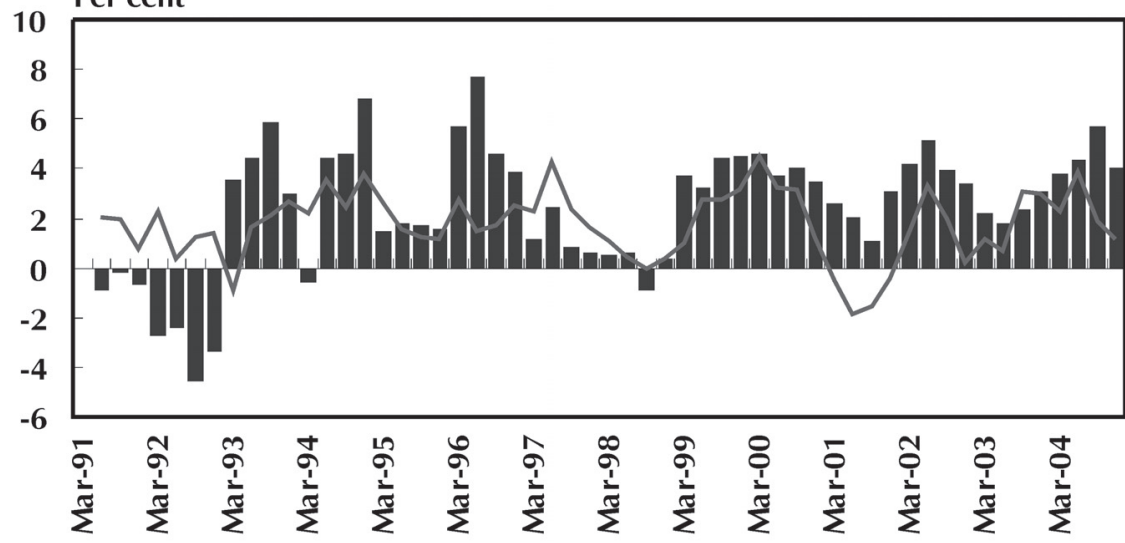

Seasonally adjusted

\section{Real GDP growth}

- World trade volume growth

Source: South African Reserve Bank and CPB Netherlands Bureau of Economic Policy Analysis

On average, South Africa exported most of its products to the US, the UK, Japan, Germany, the Netherlands, Belgium, Italy and Zimbabwe over the period 2002 to 2004. With the exception of Zimbabwe, these countries are among the world's largest economies and the US, the UK, Japan and Germany alone, on average accounted for more than half of world GDP for the period 2002 to 2004. Figure 14 illustrates that annual changes in the South
African business cycle, in general, track those of its major trading-partner countries, with a clear lead for the trading-partner countries. The synchronisation of business cycles might be the consequence of trade and financial (and corporate) linkages between the countries and/ or confidence spill-overs. Conversely, it might also reflect the fact that South Africa and its trading partners have been hit by common shocks.

Figure 14

Coincident business cycle indicators of South Africa and main trading partners

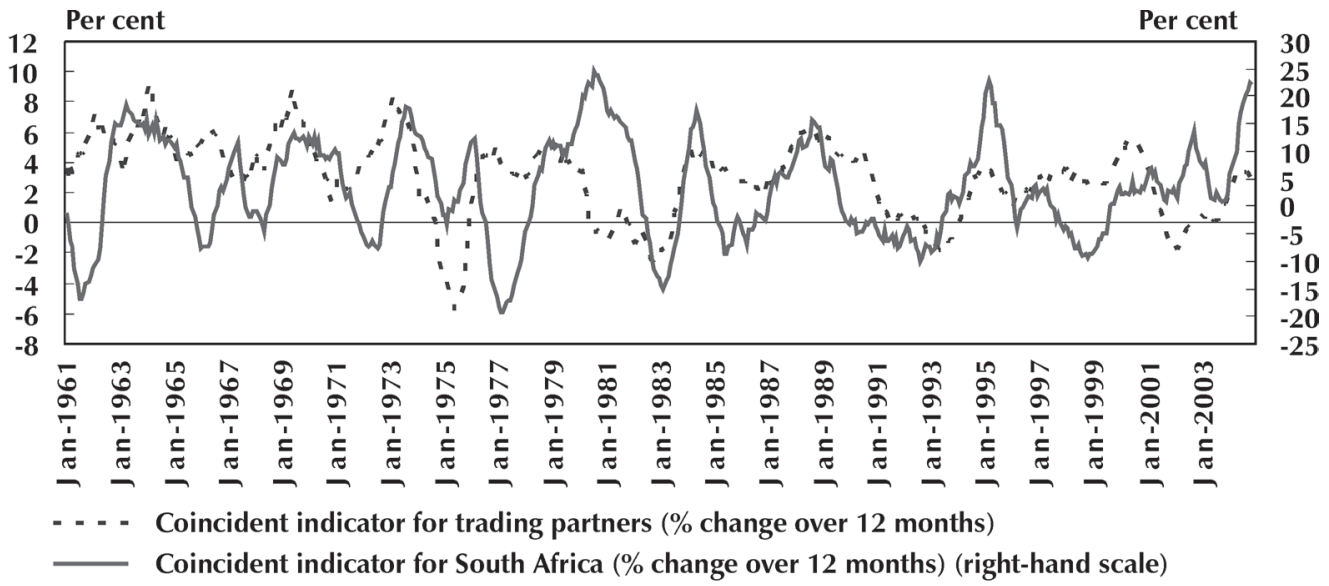


The statistical significant correlation coefficient between the South African and trading partners' business cycles over the period January 1961 to November 2004 is 0.2. However, the average picture conceals large differences depending on the sub-periods considered. Figure 15 displays the correlation between the annual rates of change in the domestic and foreign business cycles for five different periods. For all periods, the correlation is calculated for various lags of the South African economy. In the 1960s, the highest correlations are reached after zero and 14-16 lags. In the 1970s and 1980s, the highest correlation of business cycles is reached without any lag. This might suggest that both regions have been hit by common external shocks. This could be expected in the light of South Africa's isolation from the rest of the world during these periods due to international sanctions. The highest correlation in the 1990s is reached when South Africa lagged by 11 months. A longer lag (16 months) was registered during the period since 2000. The significance of lags after the 1990s could be expected due to South Africa's reintegration into the world economy. In addition to the role of common shocks that could have contributed to the synchronisation of business cycles (as reflected in the higher correlation coefficients for 0-3 lags), the significance of even higher correlation coefficients with additionally longer lags since the 1990s may reflect the impact of increased trade and financial linkages between the two regions.

Figure 15

Correlation between South African and foreign business cycles

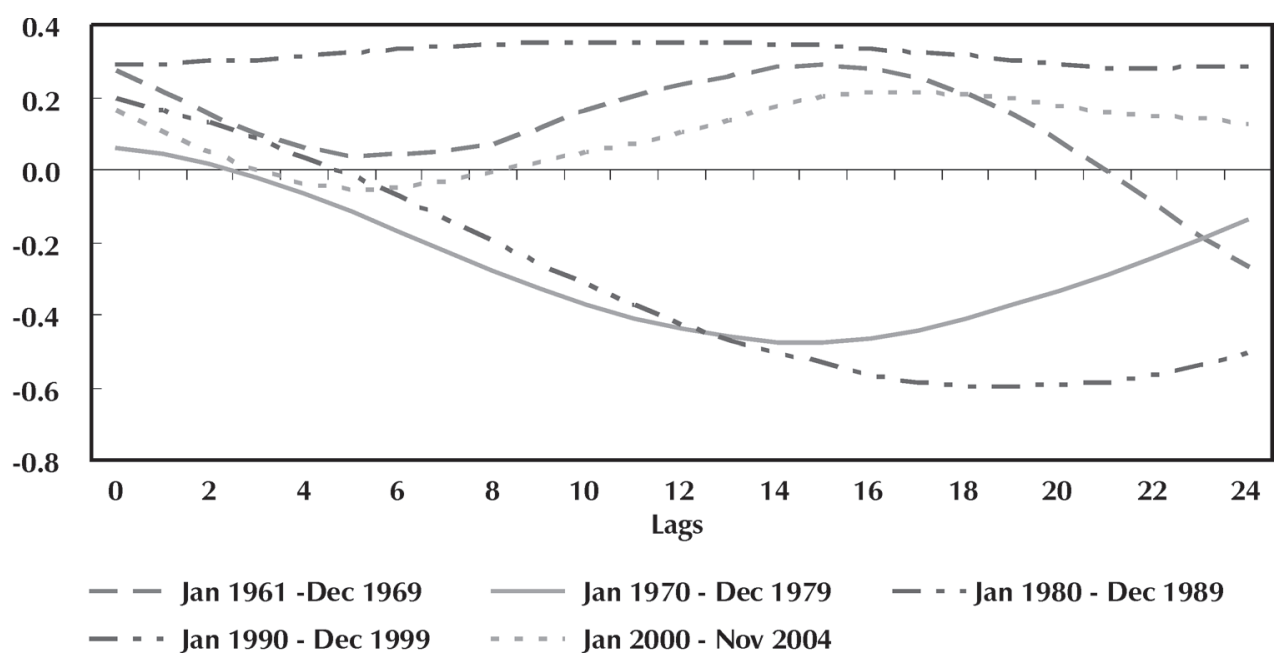

Source: South African Reserve Bank and own calculations

Figure 16 provides further evidence that trading-partner growth matters to the South African economy, particularly during the recent world economic slowdown and the subsequent recovery. Stronger growth rates in major trading-partner economies, in particular, supported exports over the past couple of years when South Africa experienced a large loss in competitiveness due to the strong appreciation of the rand as illustrated earlier. 


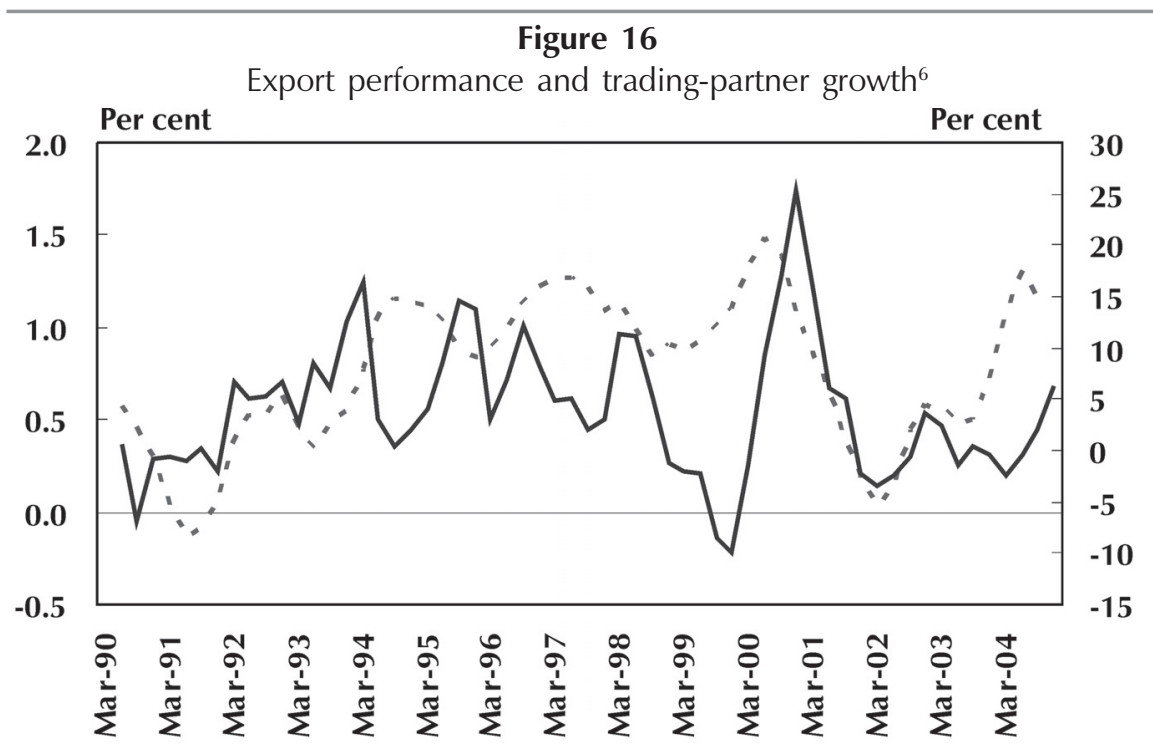

- - - Weighted annual real GDP growth of major trading partners (2QMA)

Annual export volume growth (right-hand scale) (2QMA)

Source: South African Reserve Bank and own calculations

Apart from the synchronisation in business cycles and the importance of foreign demand for South African exports, Figure 17 illustrates that South Africa's stock market to some extent is also related to those of its trading partners. The South African stock market has been slightly more correlated to the US market (statistical significant correlation coefficient of
0.35) compared to the euro area stock market (statistical significant correlation coefficient of 0.24 ) since mid-1995. For the period since mid2002, the statistical significant correlation coefficients between South Africa's stock market and the US and euro area markets are much stronger (around 0.85).

Figure 17

South African and foreign stock markets

Index (July $1995=100)$

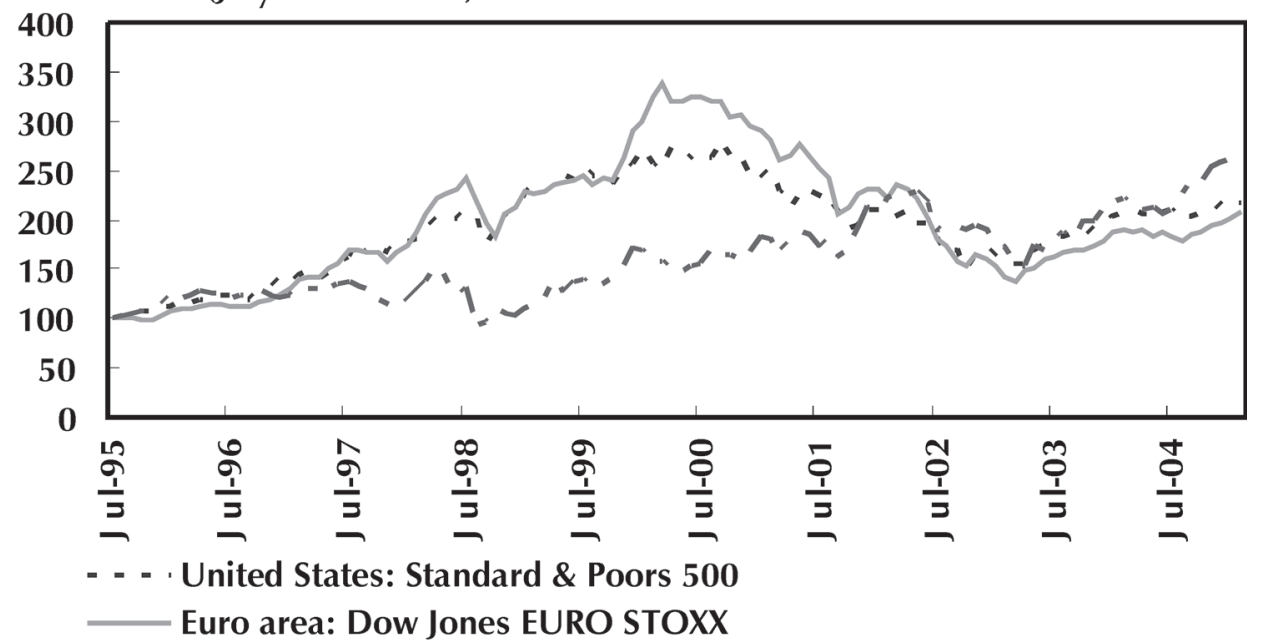

- - South Africa: JSE All share 
In summary, South Africa's openness to trade does seem to create opportunities to enhance growth through international trade. Stronger growth in trading partner countries in particular, supported South African exports over the last couple of years, when South Africa experienced a large loss in international competitiveness due to the strong appreciation of the domestic currency. South Africa's business cycle in general tracks those of its trading partners closely, with a slight lag. Stock market movements between South Africa and its major trading partners are also closely related.

With regards to other empirical evidence on the South African economy, Cassim Onyango and Van Seventer (2004: 142) maintain that the economy-wide impact that the trade reform process has had on the South African economy is still open to debate. This is due to the multifaceted nature of trade liberalisation. Loots (2002:17) also highlights that the impact of globalisation on the South African economy is complex, but argues that economic globalisation has had a definite positive impact on the South African economy. A recent publication of the International Monetary Fund (IMF) stated that trade liberalisation has contributed significantly to the growth process in South Africa through increases in total factor productivity. According to the IMF (2006: 8) total factor productivity growth has accounted for about one-half of the economic growth recorded in South Africa since 1994. Virtually all of South Africa's factor productivity growth has emanated from the greater openness of the economy and increased integration with overseas markets.

Figure 18

Volatility of domestic economic growth and external factors

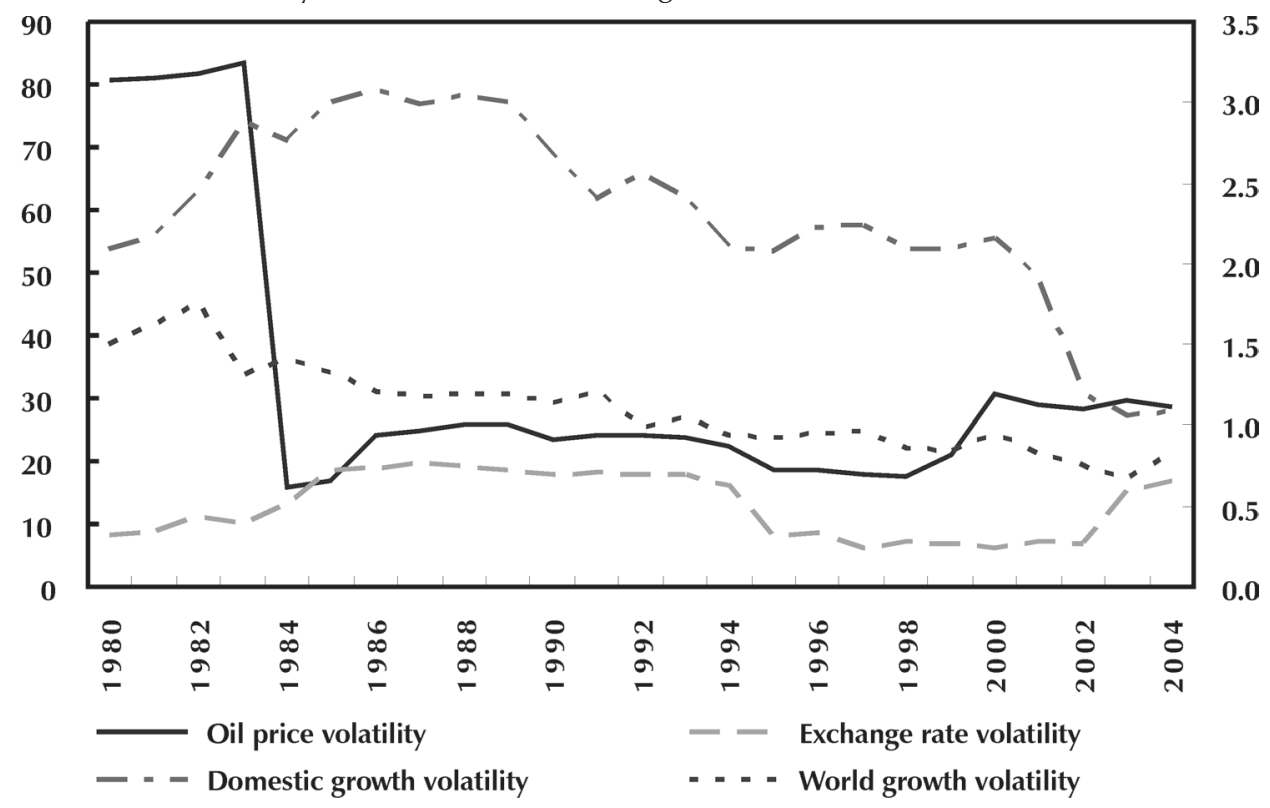

Source: South African Reserve Bank, IMF and own calculations

\subsection{Other remarks}

In order to investigate whether output fluctuations in South Africa are driven by global economic events, Figure 18 illustrates the volatility in domestic and world economic growth, the exchange rate and the oil price. The four lines of growth depict the 10-year rolling standard deviations of domestic and world real GDP growth, the annual rate of change in the real rand price of oil and the annual rate of change in the rand/US\$ bilateral exchange rate. The downward trend in domestic economic growth volatility since 1987 , is in line with developments in world economic growth 
volatility. The volatility of oil prices and the exchange rate, however, have increased in recent years. Oil price volatility seems to be unrelated to domestic economic growth volatility. Over the period 1980 to 2004, the highest statistical significant correlation was found between domestic real economic growth volatility and world economic growth volatility (correlation coefficient of 0,6 ) and exchange rate volatility (correlation coefficient of 0,4 ) respectively. It is also clear from Figure 18 that the recent large movements in the exchange rate did not have any major impact on domestic economic growth volatility. The statistical significant correlation coefficient between domestic economic growth volatility and the volatility in the exchange rate over the period 1980 to 2000, for example, is much stronger (0.7).

To illustrate this point further, Figure 19 illustrates 10-year rolling correlations between domestic economic growth and foreign economic factors. Whereas the correlation between domestic and foreign economic growth remained relatively high since the early 1990s, the correlation between the exchange rate and domestic economic growth has dropped significantly and has even become negative again. Figure 18 suggests that, as measured by this simple metric, world economic growth has become an increasingly important factor in explaining trends in domestic economic growth since the 1990s. On the other hand, the inverse relationship between exchange rate movements and domestic economic growth seems to have weakened again. The rolling correlations suggest that annual changes in the real rand price of oil are positively related to real GDP growth. This might be explained by the fact that this analysis does not take account of lagged effects, which might be important in the case of severe negative oil price shocks?

Figure 19

Rolling correlations between domestic economic growth and international economic factors

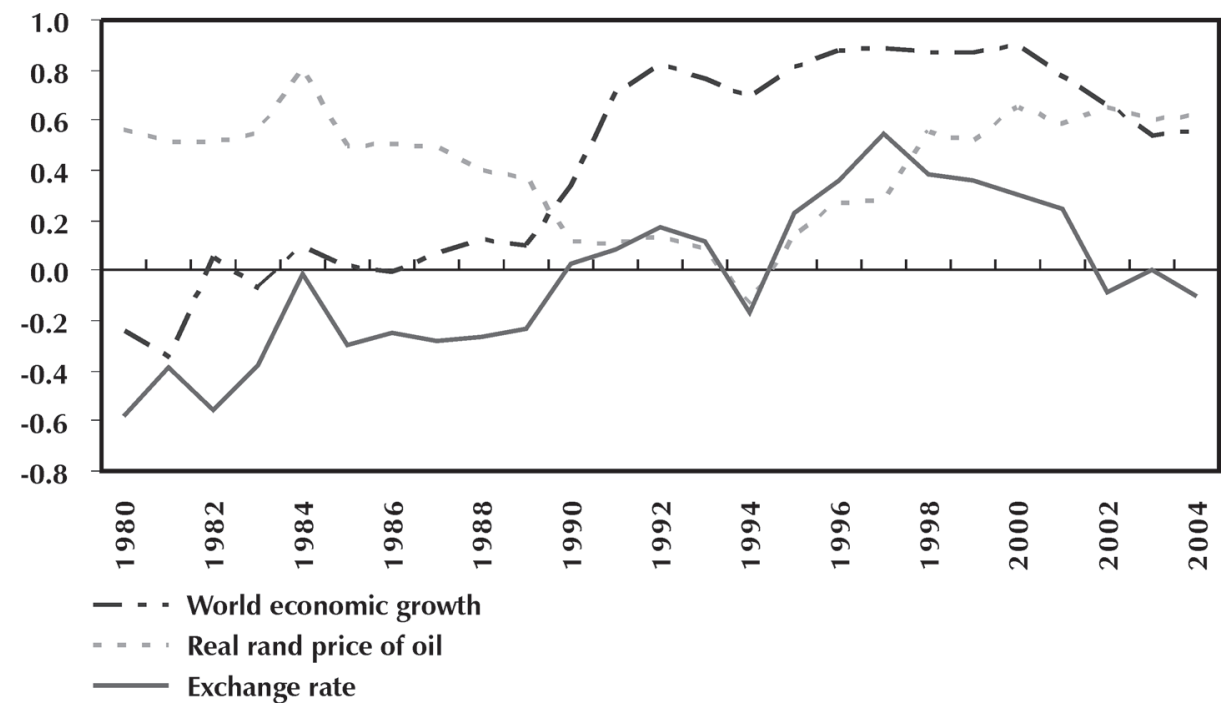

Source: South African Reserve Bank, IMF and own calculations

So far, the analysis of the impact of international economic developments on the South African economy focused mainly on three aspects, namely oil prices, the exchange rate and openness to trade. However, there are many other factors and events that could also impact on a domestic economy. One of these factors is the economic consequences of international conflict. While the overriding concern of war must inevitably be the human cost, its impact on the world economy also needs to be considered. According to Leach (2003), the macroeconomic impact of war is highly uncertain - it could be negative or positive. The 
impact depends on the extent and duration of the conflict, a possible oil price spike, the impact on consumer and business confidence, on the exchange rate, equity prices, aggregate demand from higher defence spending and the potential response of monetary and fiscal policies. Tourism and international travel could be negatively affected, similar to the aftermath of the 11 September 2001 events. Moreover, international conflict could hamper international trade by continued geopolitical tensions and a worsening of trade relations. Reduced profit and demand expectations could impact on equity prices, placing weight on consumption and investment via reduced financial wealth and higher capital costs. The impact of conflict on the exchange rate is more complicated. Traditionally, the US dollar has served as a safe-haven currency in times of geopolitical crises. Similarly, rising oil prices generally raise the demand for dollars. The combined effect could therefore be US dollar appreciation and thus exchange rate depreciation for other countries. It is also very likely that the volatility in bilateral exchange rates with the United States might increase in times of international conflict. The influence of any conflict on the US economy has a considerable effect, due to its significance as an engine of growth for the world economy. Arora \& Vamvakidis (2001) found that during the past few decades, growth in the US has had a profound impact on growth in the rest of the world, especially in developing countries. This confirms its significance as a global trading partner. Conflicts in the Middle East also have a major influence, as the region is associated with core oil supply. Disruption in oil supplies affect the oil price, which negatively impacts the entire world economy.

Past experience shows that great geopolitical crises did not have a serious direct impact on confidence levels and the exchange rate in South Africa. As illustrated in Figure 20, the invasion of Kuwait in August 1990 was accompanied by a decline in household and business sentiment, but the loss of confidence was temporarily restored by the success of the Desert Storm operation. However, business confidence was already declining since mid-1998 and the NATO air strikes on Serbia in March 1999 and the 11 September 2001 attacks in the United States did not seem to affect confidence levels much in South Africa. Moreover, apart from the possible impact of geopolitical tensions on the strong depreciation of the rand in 2001, earlier episodes of conflict since the 1990s did not seem to significantly affect exchange rate developments in South Africa.

Figure 20

International conflict and its impact on the South African economy

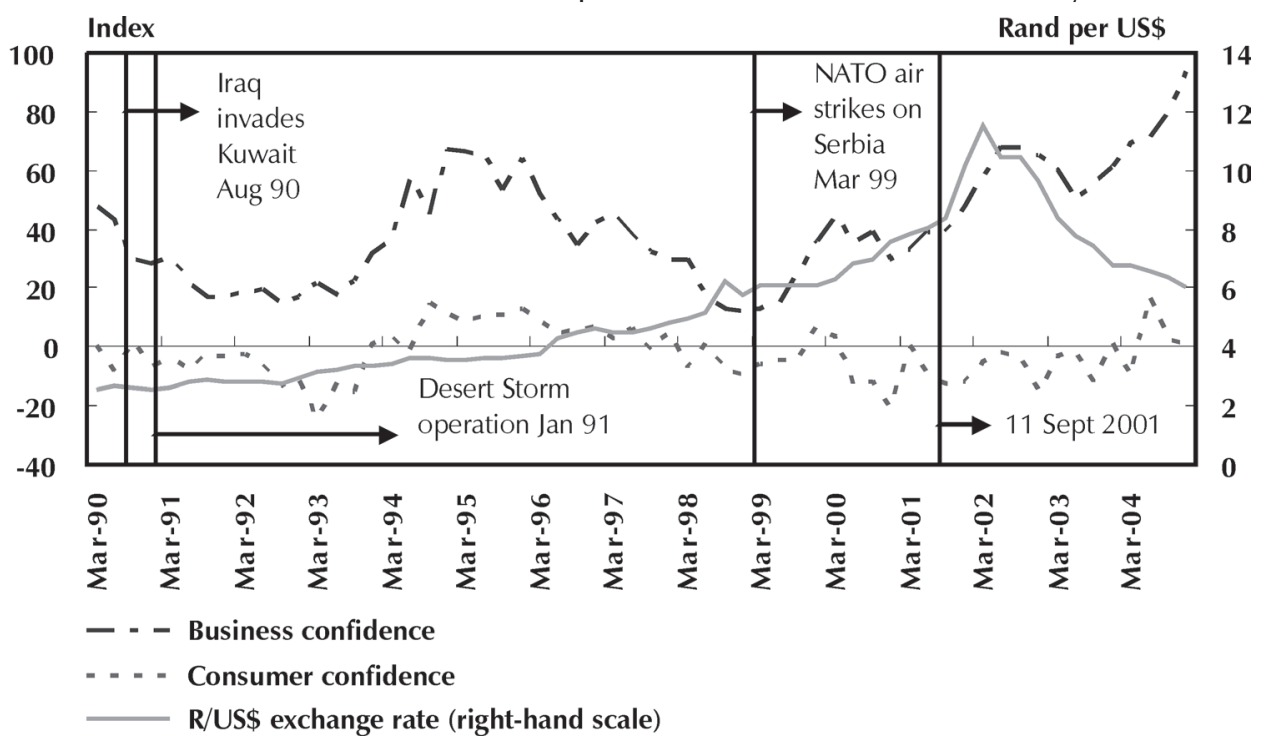

Source: South African Reserve Bank, Bureau for Economic Research and own calculations 
The impact of international financial crises can also be very harmful to domestic economic growth and global economic stability. Some recent examples are the successive waves of financial turmoil that began with the Mexican crisis in 1994-95, which hit Thailand, Indonesia and Korea in 1997-98, followed by the Russian debt default in 1998, the Brazilian crisis in 1999 and the Turkish and Argentine crises in 20012002. Several of these events led to financial losses well in excess of 10 per cent of national income in the affected country (Knight, 2004). Each crisis exposed weaknesses in the financial system that accentuated the severity of the economic downturns that ensued. Financial crises are usually characterised by sharp depreciating currencies and collapsing asset prices that lead to acute financial sector distress. Financial crises in foreign countries can impact on other countries via short-term effects in bond and equity markets and on the exchange rate. They also have longer-term implications for trade and foreign investment (see Centre for Research into Economics and Finance in Southern Africa, 1997: 31-35).

Regarding the South African situation, Harris (1999) finds that South Africa was the only country in Sub-Saharan Africa that had been significantly affected by the Asian Crisis through financial channels. South Africa is the only country in this region with sophisticated financial markets and substantial private capital inflows, and as a result was fully exposed to contagion. South Africa was largely insulated from the Asian Crisis in its first phase and was only affected by the collapse of the Hang Seng and other major stock markets (Centre for Research into Economics and Finance in Southern Africa, 1997). Despite sharp falls in the Johannesburg Stock Exchange, the effects of the crisis on the volume of portfolio flows into South Africa were mixed and the impact on the exchange rate was limited.

\section{3}

\section{Conclusion}

The ongoing globalisation process, South Africa's reintegration into the world economy after years of apartheid-induced isolation, the openness of the South African economy, the volatility in the domestic currency and international oil prices in recent years, recent occurrences of international natural disasters, financial crises, diseases, wars etc. all add to the question of how much South Africa's economic performance depends on economic conditions in the rest of the world.

The results of this paper have shown that international economic developments decidedly influence the South African economy. In general, the results have shown that external shocks have affected South African output, inflation, interest rates, the stock market, economic confidence, competitiveness, capital flows etc. over time and that these shocks should be seen as potential threats to domestic growth and an important source of volatility. Moreover, the importance on domestic growth of economic developments on South Africa's trading-partner countries was highlighted by the importance of foreign demand for South African exports as well as the relatively close synchronisation of domestic and foreign business cycles and stock markets. Any shock that negatively impacts on South Africa's trading-partner countries, therefore holds important implications for the domestic economy. To this extent, the occurrence of recent cases of disease, war and natural disasters in foreign countries could be potentially harmful to domestic growth if these events impact on South Africa's main trading-partner countries.

Globalisation accelerates and spreads the international consequences of domestic policies. No country can escape the consequences of globalisation, and all countries are being called upon to ensure prudent macroeconomic policies and the robustness of financial systems. The challenge to policymakers is to build on the prospects for mediumterm growth, and to draft policies that will equip them better to weather inevitable future fluctuations in the international economy. The increased risk of exposure to spill-over effects of economic and financial disturbances necessitates a closer analysis of economic developments from a worldwide perspective. 
Although this paper provides some evidence of the importance of international economic developments for the South African economy, many unresolved questions and avenues for future research remain. The impact of foreign economic developments on domestic growth, as well as the relative importance of each shock, needs to be properly quantified. There may be many other important factors in addition to the few mentioned in this paper. Finally, the analysis was conducted in a partial equilibrium setting. Although this approach has the appealing property of simplicity, it does not adequately account for situations when feedback effects and interrelationships from external shocks are considered to be significant. Finally, the arguments put forward in this paper should be validated by more rigorous econometric investigation.

\section{Endnotes}

1 The author is grateful to Logan Rangasamy of the SA Reserve Bank's Research Department and Jan de Jager of the National Productivity Institute for their valuable comments and suggestions.

2 The real rand price of oil was calculated as ((oil price*exchange rate/consumer price index). The bank rate (lowest rediscount rate at the South African Reserve Bank) was used as the official interest rate variable. The 91-days Treasury bill rate was used as the short-term interest rate variable, while the 10 -year yield on government bonds was used as the long-term interest rate variable.

3 The decision $\mathrm{I}(0)(\mathrm{I}(1))$ was based on whether the ADF statistic for each variable (the first difference of each variable) was significant at the 5-per-cent level. The test results on consumer prices for metropolitan areas (cpi) are less clearcut due to the fact that inflation in many cases is a borderline case between an $\mathrm{I}(0)$ and an $\mathrm{I}(1)$ process.

4 By estimating the model in this way, the possibility of cointegration among the log levels of the variables is ignored.

5 2QMA means two-quarter moving average.

6 Weights are based on the share of South African exports to these countries over the period 2002 to 2004. Countries included are the United States of America, the United Kingdom, the Netherlands, Germany (from 1992) and Japan (from 1995). In total, these countries account for about 40 per cent of South Africa's exports.

2QMA means two-quarter moving average.

7 While a visual examination of the data is illuminating, it is hard to impute the direction of causality. In order to investigate the causal relationship running from international economic developments to domestic economic growth (and domestic economic growth volatility), Granger causality tests were performed for the period 1980 to 2004 . The only significant causal relationship that was found was that between world economic growth volatility to domestic economic growth volatility.

\section{References}

1 ARORA, V. \& VAMVAKIDIS, A. (2001) "The impact of US economic growth on the rest of the world: How much does it matter?", IMF Working Paper No 119.

2 BALDWIN, R.E. (2003) "Openness and growth: What's the empirical relationship?", NBER Working Paper No 9578.

3 BROWN, P.A. \& YUCEL, M.K. (2001) "Energy prices and aggregate economic activity: An interpretative study", Federal Reserve Bank of Dallas Working Paper No 2.

4 BUREAU FOR ECONOMIC RESEARCH $R M B / B E R$ Business Confidence Index, University of Stellenbosch.

5 BUREAU FOR ECONOMIC RESEARCH "FNB/BER Consumer Confidence Index", University of Stellenbosch.

6 CASSIM, R.; ONYANGO, D. \& VAN SEVENTER, D.E. (2004) The State of Trade Policy in South Africa, Johannesburg: TIPS.

7 CENTRE FOR RESEARCH INTO ECONOMICS AND FINANCE IN SOUTHERN AFRICA. (1997) Quarterly Review, October.

8 CPB Netherlands Bureau for Economic Policy Analysis "Monthly World Trade Monitor".

9 EHRMANN, E.; FRATZSCHER, M. \& RIGOBON, R. (2004) "An international financial transmission model", Unpublished. New York: Federal Reserve Bank of New York.

10 EUROPEAN CENTRAL BANK (2004) Monthly Bulletin, November.

11 EUROPEAN COMMISSION (2004) Quarterly Report on the Euro Area, March.

12 HARRIS, H. (1999) "Impact of the Asian Crisis on Sub-Saharan Africa", Finance and Development, March. 
13 INTERNATIONAL ENERGY AGENCY (2004) Analysis of the Impact of High Oil Prices on the Global Economy, May.

14 INTERNATIONAL MONETARY FUND (2005) World Economic Outlook Database, April.

15 INTERNATIONAL MONETARY FUND (2006) Post-Apartheid South Africa: The First Ten Years, M Nowak and L.C. Ricci (eds.) January.

16 KNIGHT, M. (2004) "The vulnerability of emerging markets to shocks: What has changed since the mid-1990s?", Speech by Malcolm Knight, General Manager of the BIS, at the Toronto Centre Executive Forum, 9 November.

17 LEACH, G. (2003) "War and the world economy”, Institute of Directors Economic Paper, January.
18 LOOTS, E. (2002) Globalisation and Economic Growth in South Africa: Do We Benefit from Trade and Financial Liberalisation? Johannesburg: TIPS.

19 SOUTH AFRICAN RESERVE BANK Quarterly Bulletin (various issues).

20 SWANEPOEL, J.A. (2005) "The impact of external shocks on South African inflation at different price stages", South African Reserve Bank Discussion Paper No 3.

21 TSIKATA, Y.M. (1999) "Liberalization and trade performance in South Africa", World Bank Discussion Paper No 13. 